\title{
Effects of Big Five Personality Traits and Fear of Negative Evaluation on Foreign Language Anxiety
}

\author{
Jelisaveta Šafranj and Jelena Zivlak \\ Department of Fundamental Sciences in Engineering, Faculty of Technical Sciences, \\ University of Novi Sad
}

\section{Abstract}

The paper deals with the effects of Big Five Personality Traits and Fear of Negative Evaluation on Foreign Language Anxiety. The research problem relates to the way in which foreign language anxiety (FLA) is conditioned by certain personality traits when applying the Big Five Model, based on statistically controlled variables such as self-assessment of language mastery, fluency, frequency of reading texts in English, and length of language learning. This problem has been rather neglected in research so far. A sample of 296 students completed three questionnaires: International Personality Item Pool (Goldberg, 2001), Foreign Language Classroom Anxiety Scale (Horwitz, Horwitz, \& Cope, 1986), and the brief version of the Fear of Negative Evaluation Scale (Leary, 1983) translated into Serbian, and three additional questions related to self-assessment of reading comprehension, frequency of reading English texts and verbal fluency. The results show that low levels of Emotional stability were a consistent predictor of high levels of general language anxiety and its types as defined through scores on subscales. Also, students prone to fear of negative evaluation were more inclined to experience FLA. Since the correlation between FNE and Fear of feedback by peers and teachers is only moderate, it can be concluded that FLA is not only a consequence of the general fear of negative evaluation. High Conscientiousness proved to be a specific predictor of the high level of Communication apprehension.

Key words: anxiety; evaluation; feedback by peers and teachers; foreign language learning; predictors. 


\section{Introduction}

Language anxiety has a major impact on foreign language learning, and it is a reaction that students perceive as a threat to their sense of security or self-confidence (Spielberger, Anton, \& Bedell, 1976). Language anxiety can be described as a subjective sense of tension, fear, nervousness, and worry that occurs when learning a foreign language, or more precisely as a fear experienced when we are required to use a foreign language which is insufficiently mastered. At the same time, it is an unpleasant sense of anxiety combined with one or several body sensations, e.g. butterflies in the stomach, chest pressures, heart palpitations, rapid breathing, or a headache. The increasing number of research studies resulted in classifications of language anxiety in literature, which distinguish trait anxiety, state anxiety, and situation-specific anxiety (MacIntyre \& Gardner, 1991).

Trait anxiety is defined as a personality trait of feeling anxiety in any situation (Spielberger, 1983) and as a permanent predisposition to the feeling.

As opposed to the relatively stable emotional state that occurs when describing trait anxiety, state anxiety is an instant and not always present trait, e.g. it is manifested before an important exam (MacIntyre \& Gardner, 1991).

Situation-specific anxiety is the third type of anxiety, and it is defined as unpleasantness that respondents feel at a certain time as their reaction to a particular situation (Woodrow, 2006).

This type of anxiety substantially facilitates language anxiety research, since various aspects leading to this condition can be considered.

There are many theories regarding the causes of language anxiety. Horwitz and Young (1991) suggest that it can be seen as a manifestation of other forms of anxiety, such as oral communication apprehension, fear of negative social evaluation and (language) test anxiety.

McCroskey (1977) defines oral communication apprehension as an individual level of anxiety associated with an actual or expected conversation with another person. Horwitz et al. (1986) incorporated this definition of oral communication apprehension into their concept of anxiety in foreign language learning.

Fear of feedback by peers and teachers is a broader concept, since it does not depend on the situation. MacIntyre and Gardner (1991) suggest that when students are uncertain about what they are saying, they are afraid of losing their public image, and begin to doubt their ability to leave a positive impression. The above authors suggest that due to this fear, students often react passively, refusing to participate in any activity that could affect the improvement of their linguistic abilities. In some cases, students deliberately skip foreign language classes to avoid unpleasant situations that make them feel they are lagging behind others (MacIntyre \& Gardner, 1991; Tzoannopoulou, 2016).

Test anxiety can be noticed in students who have completed their test poorly and consequently develop negative attitudes towards evaluation and fail to understand 
how they are assessed (Sarason, 1984). Test anxiety is most commonly recognized in students who have performed poorly in previous tests, and often convey these attitudes unconsciously to other school subjects including foreign language. They often set unrealistic demands for themselves, considering all but perfect results a failure (Horwitz et al., 1986). Test anxiety has appeared as a consequence of several factors, such as students' attitudes toward language learning and study skills (Shohamy, 1982), time limit, personal variables, such as gender, age, educational and economic background (Madsen, 1982; Putwain, 2007).

Chamorro, Ahmetoglu, and Furnham (2008) investigated the dispositional determinants of test anxiety among American and British undergraduate students. The participants' self-assessed intelligence, personality, and self-evaluation were specified as the determinants of test anxiety. As indicated by the obtained results, test anxiety was positively correlated with the participants' neuroticism and self-evaluation; and negatively correlated with agreeableness, openness, and conscientiousness. In addition, a strong direct path from neuroticism to test anxiety was indicated by structural equation modelling results; as well as a moderate direct effect of extraversion on test anxiety.

Aydın, Yavuz, and Yeşilyurt (2006) studied test anxiety, its rationale and its effects on foreign language learning in the Turkish university context. The obtained results indicated that test anxiety provoking factors were the low level of learners' English language proficiency, students' attitudes toward language learning, and teachers' negative attitudes towards test, parental expectations, and fear of negative evaluation. In addition, it was proved that test anxiety causes physical and psychological problems by affecting concentration, motivation, and increasing errors in language learning. Furthermore, El-Zahhar and Hocever (1991) noted that test anxiety in Brazil, the USA, and Arabic countries results from the extreme consequences related to accomplishments on examinations, particularly in secondary schools.

Horwitz et al. (1986) have contributed to the study of this issue by creating the Foreign Language Classroom Anxiety Scale (FLCAS). This instrument was designed with the intention to measure the level of anxiety specific to foreign language learning, and due to its high-quality and reliability, it is widely used in surveys.

\section{The Big Five Personality Traits and Fear of Negative Evaluation}

Personality traits can be significant determinants of language anxiety, and therefore, the Five Factor Model (FFM) is of substantial importance for this research. The Big Five Personality Traits, also known as the Five Factor Model (FFM) originates from the 1930s, but since the 1980s it has been widely adopted by a number of personality psychologists (Goldberg, 1992). This empirical model suggests five broad dimensions used by psychologists to describe human personality. These five dimensions are specified as openness to experience, conscientiousness, extraversion, agreeableness, and neuroticism. Each of the suggested factors consists of various correlated and more precise primary characteristics such as: 
Openness to experience (inventive/curious vs. consistent/cautious). It is related to the positive reception of adventure, art, curiosity, unusual ideas, emotions, and numerous other experiences. Openness indicates a preference for innovations and variety, creativity and the degree of intellectual curiosity. High openness can be regarded as unpredictability or lack of focus while people with low openness are trying to find satisfaction through well-known things and actions (Toegel \& Barsoux, 2012). Openness to experience is sometimes linked to intellectual ability or intellect.

Conscientiousness (efficient/organized vs. negligent/careless). It indicates an inclination to be dependable and organized, perform dutifully, demonstrate selfdiscipline, aspire for accomplishment, and favour planned rather than spontaneous behaviour. High conscientiousness is frequently understood as stubbornness and obsession while Low conscientiousness is connected with flexibility and spontaneity (Toegel \& Barsoux, 2012).

Extraversion (outgoing/energetic vs. solitary/reserved). This refers to vigour, affirmative sentiment, surgency, fierceness, sociability and the inclination to seek stimulation in the company of others, and talkativeness. High extraversion is often regarded as authoritarian and attention-seeking while low extraversion indicates a reticent, reflective personality (Toegel \& Barsoux, 2012).

Agreeableness (friendly/compassionate vs. challenging/detached). This trait refers to an inclination to be empathetic and cooperative rather than apprehensive and antagonistic towards others. It is also about one's trusting and supportive nature, and whether an individual is generally well-tempered or not. High agreeableness is often seen as naive or submissive while low agreeableness personalities are often competitive or demanding people (Toegel \& Barsoux, 2012).

Neuroticism (sensitive/nervous vs. secure/confident). This points to an inclination to suffer unpleasant emotions easily, such as irritation, depression, anxiety, and susceptibility. Neuroticism also refers to impulse control and degree of emotional stability. A high need for stability is regarded as steady and collected personality, and a low need for stability causes a spontaneous and excitable personality (Toegel \& Barsoux, 2012).

The Big Five Personality Model was examined by several researchers in relation with different constructs considering foreign language learning, such as communicative competence (Verhoeven \& Vermeer, 2002), emotional and academic intelligence (Zee, Thijs, \& Schakel, 2002), willingness to communicate (Öz, 2014), and language learning strategies (Asmall, 2014). However, research on the studies conducted to reveal the relationship between the Big Five Personality Traits and language learning anxiety is rare.

In the research carried out by McIlroy, Bunting, and Adamson (2000) test anxiety was investigated to find out whether it is appropriate for a four-factor structure (tension, worry, bodily symptoms, and test irrelevant thoughts) in an Irish sample, and 
its relationships with academic performance and personality were tested. The results indicated that self-efficacy had the apparent and steady relationship to the four test anxiety factors. There was also a relationship between 'conscientiousness' and test anxiety.

Khosravi and Bigdely (2008) examined some personality factors such as extraversion, introversion, and neuroticism, and their interaction with test anxiety. The findings showed that test anxiety was considerably and positively correlated with neuroticism. No significant correlations were determined between test anxiety and extraversion and introversion.

Asmali (2017) investigated the Big Five Personality Traits and test anxiety of Turkish EFL learners. The findings confirmed that participants showed a moderate level of test anxiety. Negative relationships between test anxiety and personality traits of emotional stability, imagination, and extraversion were proved in the study. Regression analyses extensively acknowledged emotional stability, and imagination personality traits as predictors of test anxiety.

A recent study (Tzoannopoulou, 2016) investigated the relationship between language anxiety and fear of negative evaluation in a group of Greek students. The obtained results revealed a significant effect for foreign language learning anxiety and fear of negative evaluation in relation to gender and performance. Female students at an intermediate/upper intermediate level were more anxious and more inclined to fear of negative evaluation than male students at the same level.

Therefore, this research aims to fill the gap in the literature considering the relationship between the Big Five Personality Traits and foreign language learning anxiety among students at the university level. Additionally, this research takes into account fear of negative evaluation while testing its contribution in predicting foreign language anxiety independent of personality traits.

Fear of negative evaluation is one of the aspects of social anxiety (Schlenker \& Leary, 1982) and refers to the degree to which individuals are apprehensive of being negatively evaluated. The fear can arise when one thinks about evaluation that may follow or the current evaluation. People with expressed fear are more suspicious of their own ability to make others feel they are desirable (Schlenker \& Leary, 1982). Fear of negative evaluation is negatively linked with self-esteem, and positively with situational anxiety and shyness. People who feel more afraid of negative evaluation are more motivated to gain social approval and are more afraid of reactions of disapproval than individuals with less fear (Leary, Springer, Negel, Ansell, \& Evans, 1998).

According to previous research, the participants were found to be less anxious when they were less afraid of negative evaluation (Leary et al., 1998; Schlenker \& Leary, 1982). In addition, negative relationships have been identified between test anxiety and personality traits of emotional stability, imagination, and extraversion (Khosravi \& Bigdely, 2008). Thus, emotional stability and imagination were identified as personality traits predicting test anxiety. 
Personality traits are relatively permanent and unchanging characteristics of individuals when particular regularities are expected in the prediction, or when it is established that certain individuals have a specific predisposition to experience language anxiety. In that case, the conditions in which they take a foreign language exam could be modified, or some additional interventions could be done, so the students could learn skills to cope with test anxiety and give way to comfortable and encouraging feelings. In addition, this study may provide some evidence on issues pertaining to foreign language anxiety and fear of negative evaluation, an area that has attracted little attention in the university context. Several directions focusing on the relationship between fear of negative evaluation, language anxiety, learning strategies, and personality could provide further advancement in language learning as well.

\section{Research Subject and Objectives}

The focus of this research are personality traits (operationalized through the Big Five Model) and the fear of negative evaluation as potential determinants of language learning anxiety. In order to obtain a clear picture of the nature of the relationship between the above variables, the following additional variables were statistically controlled: self-assessment of language proficiency, fluency, frequency of reading texts in English and the length of language learning. Thus, the aim of the study was to examine the ways personality traits predict language anxiety after removing the influence of potentially confounding variables. An additional objective was to examine whether there is an independent predictive contribution of the Fear of negative evaluation in the context of language learning anxiety, in addition to the predictive contribution of personality traits. Therefore, the following hypotheses were tested:

Hypothesis 1. Higher self-assessment of language proficiency, fluency, frequency of reading texts in English and longer language learning are negative predictors of language learning anxiety.

Hypothesis 2. Higher Emotional Stability, Intellect, and Extraversion are significant predictors of lower levels of language learning anxiety, while higher Conscientiousness predicts higher levels of language learning anxiety.

Hypothesis 3. Higher Fear of negative evaluation predicts higher language learning anxiety above and beyond personality traits.

\section{Method}

\section{Sample}

The study was carried out on a sample comprising 296 engineering students from the Faculty of Technical Sciences in Novi Sad (Table 1) who were learning English for Specific Purposes as a one-semester subject. The average age of students was 20.16 (SD $=1.4$ ), while genders were represented equally ( $48 \%$ male participants). The minimum and maximum duration of language learning among participants were 2 and 18 years $(M=12, S D=2.37)$, respectively. Power engineering students were attending 
the second year of their university education, while the other students studying civil engineering, mechanical engineering and industrial management attended the first year of their studies.

Table 1

Sample structure

\begin{tabular}{lcc}
\hline \multicolumn{1}{c}{ Department } & $\mathrm{N}$ & $\%$ \\
\hline Power Engineering & 81 & 27.4 \\
Civil Engineering & 14 & 4.7 \\
Mechanical Engineering & 41 & 13.9 \\
Industrial Management & 156 & 52.7 \\
\hline
\end{tabular}

\section{Instruments}

The Foreign Language Classroom Anxiety Scale (FLCAS; Horwitz et al., 1986) translated into the Serbian language was used in this research. FLCAS is a self-reporting measure of foreign language anxiety experienced in a classroom context. It is comprised of 33 items assessed on a 5-point Likert scale ( 1 - totally disagree, 5 - totally agree). Besides the total score $(\alpha=.94)$, three scores for subscales can be used measuring Communication apprehension (11 items, $\alpha=.86$ ), item example 9 - I start to panic when I have to speak without preparation in language class; Fear of feedback by peers and teachers ( 7 items, $\alpha=.81$ ), item example 7 - I keep thinking that the other students are better at languages than I am; and Fear of language tests ( 15 items, $\alpha=.86$ ), item example 21 - The more I study for a language test, the more confused I get. The values of the dimensions described in the context of this study serve as criterion variables.

Goldberg's Big Five Personality Traits from the International Personality Item Pool (IPIP; Goldberg, 2001) was the next instrument used in this research. The Big Five Personality Traits were assessed using Goldberg's items from the public domain, which were translated into the Serbian language. Each trait was assessed using 10 items followed by a 5 -point Likert scale ( 1 - totally disagree, 5 - totally agree). The reliability of each scale was as follows: Extraversion $\alpha=.75$, Conscientiousness $\alpha=.73$, Agreeableness $\alpha$ $=.77$, Emotional Stability/Neuroticism $\alpha=.86$ and Intellect $\alpha=.71$. Personality traits operationalized by this instrument have the status of predictor variables.

Fear of Negative Evaluation (FNE; Leary, 1983) was also used in this research. FNE is a short version of a measure of the fear of negative evaluation as one of the aspects of social anxiety. It is a 12 -item scale assessed on a 5-point Likert scale ( 0 - totally disagree, 4 - totally agree). The reliability of the Serbian translation used in this sample is $\alpha=.81$. Fear of negative evaluation is one of the predictors in the tested models.

Three additional questions were asked in order to assess students' perceived level of English comprehension (How do you perceive your own ability to understand English language?), frequency of reading contents in English (How often do you read English language texts?) and verbal fluency (How do you perceive your verbal fluency in English language?). These questions were followed by a 7-point Likert scale (1 - poor, 7 excellent). The described estimates were used as control variables, or covariates. 


\section{Results and Analyses}

Descriptive statistics for the variables used in this research were calculated and are shown in Table 2. According to skewness and kurtosis values, all scores follow a nearly normal distribution.

Table 2

Descriptive statistics for the variables used in the research ${ }^{1}$

\begin{tabular}{lccccccc}
\hline & $N$ & Min & Max & $M$ & $S D$ & $S k$ & $K u$ \\
\hline Extraversion & 296 & 15 & 49 & 32.95 & 6.32 & -0.07 & 0.04 \\
Conscientiousness & 296 & 15 & 50 & 35.74 & 6.03 & 0.00 & -0.31 \\
Agreeableness & 296 & 20 & 50 & 37.83 & 5.92 & -0.19 & -0.44 \\
Emotional stability & 296 & 12 & 50 & 32.07 & 7.85 & 0.07 & -0.30 \\
Intellect & 296 & 23 & 50 & 35.89 & 5.45 & 0.15 & -0.39 \\
Language anxiety & 296 & 37 & 157 & 87.81 & 24.28 & 0.09 & -0.13 \\
Communication apprehension & 296 & 11 & 52 & 29.02 & 8.71 & -0.11 & -0.23 \\
Fear of feedback by peers and teachers & 296 & 7 & 35 & 18.92 & 6.00 & 0.11 & -0.33 \\
Fear of language tests & 296 & 18 & 74 & 39.88 & 10.96 & 0.28 & -0.06 \\
Fear of negative evaluation & 275 & 0 & 44 & 18.75 & 8.03 & 0.14 & 0.04 \\
English comprehension & 292 & 1 & 7 & 5.27 & 1.42 & -0.61 & -0.26 \\
Reading frequency & 292 & 1 & 6 & 2.46 & 1.23 & 0.14 & -1.41 \\
Verbal fluency & 292 & 1 & 7 & 4.59 & 1.49 & -0.23 & -0.64 \\
\hline
\end{tabular}

Note: Min - Minimum, Max - Maximum, M - Mean, SD - Standard deviation, Sk - Skewness, Ku - Kurtosis.

In order to address the research questions, several hierarchical multiple regression models were tested. In the first step of each model the control variables were entered - self-assessed level of English comprehension, verbal fluency, reading frequency, as well as overall length of language learning. In the second step, five personality dimensions (Extraversion, Conscientiousness, Agreeableness, Emotional stability and Intellect) were entered as predictors and in the final step of the models Fear of negative evaluation was added. The following variables were defined as criteria - total score on the questionnaire Foreign Language Classroom Anxiety (FLCA) and scores obtained using the subscales (Communication apprehension, Fear of feedback by peers and teachers and Fear of language test). Dividing the predictor variables into the described three steps provides information on how many criterion variances can be explained only by control variables, what the percentage of variances explained independently of personality traits is, and finally whether and to what extent the explanation of the criterion is contributed by Fear of negative evaluation beyond all remaining variables in the model.

By entering the control variables in the first step, $40 \%$ of the variance was explained. Entering the values on personality dimensions and Fear of negative evaluation explained additional $10 \%$ and $1 \%$ of variance, respectively. In total, the model explained $51 \%$ of criterion variance. Each step of the model was estimated as statistically significant

\footnotetext{
${ }^{1}$ Correlation table for all variables in the study can be found in Appendix 1 of this article.
} 
(Table 3).

Table 3

Standardized partial contribution of predictors, total and relative proportion of explained variance of FLCA

\begin{tabular}{lcccc}
\hline Predictor & 1 & 2 & 3 & Tolerance \\
\hline English comprehension & $-.23^{*}$ & $-.20^{* *}$ & -.19 & .35 \\
Reading frequency & .17 & .08 & .09 & .58 \\
Verbal fluency & $-.32^{* * *}$ & $-.32^{* * *}$ & $-.30^{* * *}$ & .37 \\
Overall length of language learning & -.09 & -.09 & -.08 & .82 \\
Extraversion & & .01 & .01 & .77 \\
Conscientiousness & & .07 & .06 & .83 \\
Agreeableness & & -.02 & -.03 & .74 \\
Emotional stability & & $-.31^{* * *}$ & $-.27^{* * *}$ & .80 \\
Intellect & & -.08 & -.07 & .72 \\
Fear of negative evaluation & & & $.13^{*}$ & .80 \\
\hline$R^{2}$ & .40 & .50 & .51 & \\
$\Delta R^{2}$ & .40 & .10 & .01 & \\
$\Delta F$ & 43.18 & 10.89 & 6.95 & \\
$d f 1$ & 4 & 5 & 1 & \\
$d f 2$ & 265 & 260 & 259 & \\
$p$ & .000 & .000 & .009 & \\
\hline
\end{tabular}

Note: ${ }^{*} p<.05,{ }^{* *} p<.01,{ }^{* * *} p<.001$

The results obtained in the final step of the model suggest that only the control variable Verbal fluency was a significant predictor of the higher level of language anxiety. After controlling these variables, Emotional stability and Fear of negative evaluation were estimated as independent, significant predictors - lower score on Emotional stability and higher score on Fear of negative evaluation predicted higher scores on FLCA (Table 3).

Control variables in the first step of the model explained $39 \%$ of the variance. Personality dimensions scores and Fear of negative evaluation explained, respectively, additional $9 \%$ and $1 \%$ of the variance of the criterion variable. The model in total explained $49 \%$ of criterion. Each step of the model was estimated as statistically significant (Table 5).

In the next tested model, where Communication apprehension was used as a criterion variable (Table 6), all control variables were estimated as significant predictors. The additional variance was explained by Conscientiousness in a way that those who obtain higher scores on this personality trait are likely to obtain higher scores on Communication apprehension. The inverse pattern was obtained for Emotional stability - a higher score on this trait predicted the lower score on Communication apprehension. Fear of negative evaluation was estimated as the significant predictor, above and beyond 
all other variables.

Table 4

Standardized partial contribution of predictors, total and relative proportion of the explained variance of Communication apprehension

\begin{tabular}{lcccc}
\hline Predictor & 1 & 2 & 3 & Tolerance \\
\hline English comprehension & $-.20^{*}$ & $-.16^{*}$ & $-.16^{*}$ & .35 \\
Reading frequency & $.15^{*}$ & $.12^{*}$ & $.13^{*}$ & .58 \\
Verbal fluency & $-.32^{* * *}$ & $-.33^{* * *}$ & $-.32^{* * *}$ & .37 \\
Overall length of language learning & -.08 & -.08 & -.07 & .82 \\
Extraversion & & .02 & .02 & .77 \\
Conscientiousness & & $.10^{*}$ & $.10^{*}$ & .83 \\
Agreeableness & & -.04 & -.05 & .74 \\
Emotional stability & & $-.23^{* * *}$ & $-.25^{* * *}$ & .80 \\
Intellect & & -.08 & -.07 & .72 \\
Fear of negative evaluation & & & $.10^{*}$ & .80 \\
\hline$R 2$ & .39 & .48 & .49 & \\
$\Delta R 2$ & .39 & .09 & .01 & \\
$\Delta F$ & 42.33 & 9.28 & 4.04 & \\
$d f 1$ & 4 & 5 & 1 & \\
$d f 2$ & 265 & 260 & 259 & \\
$p$ & .000 & .000 & .045 & \\
\hline
\end{tabular}

Note: ${ }^{*} \mathrm{p}<.05,{ }^{* *} \mathrm{p}<.01,{ }^{* * *} \mathrm{p}<.001$

This model (Table 5) explained $41 \%$ of the variance in total. Thirty percent was explained by control variables, while personality dimension scores and fear of negative evaluation explained, respectively, additional $9 \%$ and $2 \%$ of the variance of the criterion variable. These relative contributions were estimated as statistically significant.

Table 5

Standardized partial contribution of predictors, total and relative proportion of the explained variance of the Fear of feedback by peers and teachers as the criterion

\begin{tabular}{lcccc}
\hline Predictor & 1 & 2 & 3 & Tolerance \\
\hline English comprehension & -.16 & -.13 & -.12 & .35 \\
Reading frequency & .09 & .05 & .06 & .58 \\
Verbal fluency & $-.32^{* * *}$ & $-.33^{* * *}$ & $-.32^{* * *}$ & .37 \\
Overall length of language learning & -.07 & -.08 & -.07 & .82 \\
Extraversion & & -.01 & .01 & .77 \\
Conscientiousness & & .09 & .08 & .83 \\
Agreeableness & & .01 & -.01 & .74 \\
Emotional stability & & $-.28^{* * *}$ & $-.23^{* * *}$ & .80 \\
Intellect & & -.09 & -.07 & .72 \\
Fear of negative evaluation & & & $.15^{* *}$ & .80 \\
$R 2$ & .30 & .39 & .41 & \\
$\Delta R 2$ & .30 & .09 & .02 & \\
$\Delta F$ & 28.51 & 7.67 & 7.60 & \\
$d f 1$ & 4 & 5 & 1 & \\
$d f 2$ & 265 & 260 & 259 &
\end{tabular}




$\begin{array}{llll}p & 000 \quad .000 \quad .006\end{array}$

Note: ${ }^{*} \mathrm{p}<.05,{ }^{* *} \mathrm{p}<.01,{ }^{* * *} \mathrm{p}<.001$

The results shown in Table 5 indicate that self-assessed verbal fluency is a significant predictor of the Fear of feedback by peers and teachers (those who perceive themselves as less fluent are prone to experience higher foreign language anxiety). Additional significant predictors were Emotional stability (negative relation) and Fear of negative evaluation.

Table 6 presents the results for the model where Fear of language tests was used as a criterion variable. Each step of this model was statistically significant and explained a total of $48 \%$ of criterion variance. After adding control variables, personality dimensions explained additional $11 \%$ of variance, and Fear of negative evaluation explained $1 \%$ more, independently of all other variables.

Table 6

Standardized partial contribution of predictors, total and relative explained variance of the Fear of language test as criterion

\begin{tabular}{lcccc}
\hline Predictor & 1 & 2 & 3 & Tolerance \\
\hline English comprehension & $-.26^{* *}$ & $-.24^{* *}$ & $-.23^{* *}$ & .35 \\
Reading frequency & .09 & .06 & .06 & .58 \\
Verbal fluency & $-.27^{* *}$ & $-.26^{* * *}$ & $-.25^{* *}$ & .37 \\
Overall length of language learning & -.09 & -.10 & -.09 & .82 \\
Extraversion & & .03 & .04 & .77 \\
Conscientiousness & & .03 & .02 & .83 \\
Agreeableness & & -.02 & -.03 & .74 \\
Emotional stability & & $-.32^{* * *}$ & $-.27^{* * *}$ & .80 \\
Intellect & & -.08 & -.06 & .72 \\
Fear of negative evaluation & & & $.12^{* *}$ & .80 \\
\hline$R 2$ & .36 & .47 & .48 & \\
$\Delta R 2$ & .36 & .11 & .01 & \\
$\Delta F$ & 37.49 & 10.12 & 6.12 & \\
$d f 1$ & 4 & 5 & 1 & \\
$d f 2$ & 265 & 260 & 259 & \\
$p$ & .000 & .000 & .014 & \\
\hline
\end{tabular}

Note: ${ }^{*} p<.05,{ }^{* *} p<.01,{ }^{* * *} p<.001$

According to the results shown in Table 6, in the final step of the tested model English comprehension, Verbal fluency, Emotional stability and Fear of negative evaluation were perceived as significant predictors.

To sum up, after controlling the perceived English comprehension, Verbal fluency, Frequency of reading texts in English and Overall length of language learning it was found that Emotional stability and Fear of negative evaluation are consistent predictors of all criteria - total score on the FLCAS, and scores on the subscales such as Communication apprehension, Fear of feedback by peers and teachers and Test anxiety in the expected 
direction. Additional significant predictor Conscientiousness was registered when Communication apprehension was used as a criterion.

\section{Discussion}

The main aim of this study was to test the predictive power of personality traits defined using the five-factor model when scores from FLCAS (total score indicating the general level of foreign language anxiety and subscale scores - Communication apprehension, Fear of feedback by peers and teachers and Fear of language tests) were set as criteria variables. For that purpose, Goldberg's items from the International Personality Item Pool (IPIP) were used as indicators of the Big Five Personality Traits: Extraversion, Conscientiousness, Agreeableness, Emotional stability, and Intellect. Before entering these variables into the model, students' self-assessed values related to English comprehension, verbal fluency, frequency of reading English texts, and the length of language learning were entered as control variables. Bearing in mind all the obtained results, it can be concluded that the research hypotheses are partially supported. When it comes to the variables used as a sort of covariates, the first hypothesis is partially confirmed. Self-assessment of verbal fluency proved to be the only negative predictor of both the total score on the Language anxiety scale and scores on subdimensions. The self-assessment of English language comprehension has proven to be a significant predictor of Communication apprehension and Fear of language tests. The frequency of reading texts in English proved to be a significant predictor of Communication apprehension only, and in the opposite direction than expected. Finally, the length of English language learning does not contribute to the prediction of the degree of language learning anxiety neither in the total score nor in the subdomains. While considering these results, several explanations can be offered. How confident one is in his/her levels of English comprehension seems to be specifically related only to Communication apprehension and Fear of language tests because these domains reflect situations when students need to demonstrate their knowledge directly. This characteristic of such situations may provoke anxiety for other reasons different from just expecting negative feedback. On the other hand, the results suggest that those who read more frequently also demonstrate higher levels of Communication apprehension. It can be assumed that those who read a lot also have rich vocabulary, but when it comes to direct communication, they may be anxious because they are not sure if they know how to correctly pronounce the words that they have learned by reading. In addition, maybe explanation can be found in other personality characteristics such as introversion, or social anxiety tendencies. Those who are more dedicated to reading may also be the ones who are not comfortable in verbal communication. Finally, those who read more frequently may, at the same time, have less experience in actual communication and language practice, leading to higher anxiety in this aspect of language knowledge demonstration.

The obtained results also suggest that, after control variables were taken into account, low levels of Emotional stability were a consistent predictor of high levels 
of general language anxiety and its types defined through scores on the subscales. This result is in line with the results of previous studies when it comes to Foreign language anxiety, and supports Hypothesis 2 . In addition, it should be kept in mind that research findings (Toegel \& Barsoux, 2012) suggest that individuals low in Emotional stability have a general tendency to experience more negative emotional reactions, and interpret information in a more negatively biased manner. Students who are low in Emotional stability probably have a tendency to worry more about their language performance expecting the negative outcome, focusing only on things that might go wrong and consequently induce the state of anxiety in the situation when they have to demonstrate their FL knowledge. Regarding the relation between Intellect and Extraversion on the one hand, and language learning anxiety on the other, Hypothesis 2 is not supported by the data, since the findings suggest that they are not significant predictors of lower levels of anxiety. The independent predictive power of Fear of negative evaluation was tested as well. The results imply that students prone to Fear of negative evaluation were more prone to FLA, which is in line with Hypothesis 3. Since the relationship among these constructs (especially between Fear of negative evaluation and Fear of feedback by peers and teachers) is only moderate, we could assume that Foreign language anxiety is not only attributable to the general fear of negative evaluation related to the social context. To clarify, students have manifested various levels of language learning anxiety regardless of their interpretation of the situation as a potential source of negative evaluation.

The results concerning the predictive contribution of Conscientiousness are in line with Hypothesis 2 in the context of Communication apprehension. It means that individuals who are more conscientious are more inclined to this kind of linguistic anxiety. Likewise, it seems that individuals who are more conscientious are more concerned about the impression they leave on others, and moreover, it is important for them to show that they have made certain effort, worked hard and intensely, which has resulted in increased anxiety especially if they estimate that they failed to prepare adequately and have the opportunity to demonstrate some knowledge in the classroom. Also, the fact that they will get immediate feedback through verbal interaction might be that specific thing which highly conscientious people are sensitive to. The fact that this specific result was captured only when scores from the subscales were used implies that it might be more appropriate and more informative for research purposes to use the subscales rather than the total score. Validation of factor structure of the Serbian translation of FLCAS is needed in order to support this assumption.

The results related to the Fear of negative evaluation are consistent with the expectations as well as the findings of the recent study (Tzoannopoulou, 2016), which indicates that the learners with higher levels of foreign language anxiety also tend to experience higher levels of fear of negative evaluation. Foreign language learning in the classrooms often requires explicit demonstration of what has been learned, creating an unpleasant context where student's abilities are evaluated. Given this information, it is important that feedback is always related to concrete behaviour and followed with 
constructive suggestions how one's language performance can be improved, rather than "attaching" the feedback to students' personality.

The findings of the study compare favourably to the results of previous studies (Cheng, Horwitz, \& Schallert, 1999; Saito \& Samimy, 1996; Sellers, 2000). All previous studies reported that high levels of anxiety could have damaging effects on students' overall foreign language performance as well as specific language skills. Exploring the "background" of foreign language anxiety in terms of personality traits and general fear of negative evaluation might be used for removing students' obstacles while using foreign language. Since language performance was not assessed in this study, it should be included in future studies with the same or similar research questions in order to test, for example, whether the relationship between personality and language performance is mediated by foreign language anxiety level.

Besides, it has been claimed that the FLCA scale measures anxiety primarily related to the speaking context, since most of the FLCAS items correspond to speaking anxiety (Aida, 1994). Certain items in the questionnaire indicate a need to address both linguistic and sociolinguistic factors in association with second language speaking. Primarily, foreign language speaking anxiety reveals itself in the students' effort to be as accurate as possible in the classroom setting. Furthermore, foreign language speaking anxiety could be the consequence of a fear of negative evaluation in general, and also of a fear of negative evaluation by the peers and the teacher. Thus, this sociolinguistic feature of classroom anxiety could result in the reduced endeavour on the part of the student and poor performance in class. Given that foreign language anxiety appears to originate from negative evaluation, the teacher's role in the classroom should be extended to include strategies that facilitate willingness to communicate with students and decrease events that could lower their self-esteem (McIntyre, 1999).

Our apprehension about being evaluated adversely by others may be recognized in numerous social psychological phenomena, including prosocial behaviour, conformity, self-presentation, social anxiety, self-serving attributions, attitude change, selfhandicapping, compliance, and social facilitation (Schlenker, 1980). People who are highly apprehensive about being perceived and evaluated negatively are also likely to escape the possibility of poor evaluations and, thus, be more open to situational factors relevant to such concerns than individuals who are less apprehensive about evaluations.

Finally, it should be emphasized that the largest percentage of the variance of variables used as the criterion in regression models was explained by control variables suggesting that a very important factor in developing FLA is students' opinion about their own abilities in using a foreign language. This also means that in future studies these variables should be controlled in order to obtain more reliable results. It also means that it is important to discuss with students their expectations from classes and their own performance. We assume that teachers are often unaware of the fact that their impression about one's knowledge is inconsistent with an opinion that 
student has for him/herself. If this is openly discussed within the class, fear among students could potentially be reduced. In line with this suggestion is also the absence of a significant predictive contribution to the variable that relates to the length of English language learning, which can be interpreted in the light of the remaining results. Although it seems intuitive that longer language learning contributes to self-confidence in knowledge and reduction in linguistic anxiety, it seems that this "objective" indicator is prevailed by subjective perception of competence and certain disposition characteristics. The study sample should be expanded to include other students' profiles as well as additional measures of trait-state anxiety to obtain more generalized results.

Even though this is the first study to our knowledge that covers at the same time a whole range of personality dimensions from the Big Five Model, the overall level of Foreign language learning anxiety, its subcomponents and the Fear of negative evaluation, it is important to point out its limitations. It is necessary to replicate the results on a larger sample of students other than those from the Faculty of Technical Sciences to increase its generalizability. In addition, final exam results should be used as an objective measure of the language learning performance. It is important to assess how foreign language anxiety can affect overall performance of students and what can be done so that its detrimental effects on students' grades can be reduced.

\section{Conclusion}

The findings of the research are consistent with the studies that proposed the link between personality traits and FLA (Dewaele, 2002, 2013; Goh, Dillon, \& Goh, 2016). In addition, it investigated the role of personality as a predictor in FLA, which was also done in the study of Er et al. (2016). Research findings suggest that students low in Emotional stability have a common predisposition to experience more negative emotional reactions since they recognize interpersonal communication in a more unpleasant manner. Thus, students low in Emotional stability show an inclination toward concern about their language performance while expecting a negative outcome. They concentrate on language presentation that might go wrong and thus, generate a state of anxiety in a situation when they have to show confidence in mastering foreign language knowledge and fluency. The significant finding is that high Emotional Stability predicted lower foreign language anxiety, which can be explained by calm and collected behaviour of emotionally stable individuals that makes them less exposed to stress when they face the pressure of using a foreign language.

This research was conducted to investigate the relationship between the Big Five Factor Markers and foreign language anxiety since these kinds of studies are limited and rare even though the personality trait such as Conscientiousness has been found a consistent predictor of academic success and positively correlated with task-focused coping and lower student stress levels in educational settings (Deary et al., 1996; Poropat, 2009). The findings of our study are consistent with the previously obtained 
results and therefore make a contribution since it is the first research carried out at the university level in Serbia and Eastern Europe.

In addition, this study examines the relationship between FLA and fear of negative evaluation, an area that has so far attracted no attention in the Serbian university context and Eastern Europe as well. The obtained results revealed a considerably negative relationship between FLA and the fear of negative evaluation, above and beyond the Big Five Personality Traits. These findings are also supported by the results of earlier studies (Aida, 1994; Cheng et al., 1999; Sellers, 2000; Tzoannopoulou, 2016).

Pedagogical implications of this study relate to the need of introducing teaching approaches that take into account certain dimensions of personality in order to reduce the level of tension in the classroom as foreign language anxiety has a distinctive negative impact on some students. In addition, it is necessary to introduce and stimulate the atmosphere of relaxed dialogue with mutual respect, and students should raise their awareness of empathy and tolerance. Teachers should help students to overcome unrealistic expectations about learning a language by reminding them that successful learning involves making mistakes and that they are unlikely an indicator of failure. Students should be encouraged to take part in dialogues and actively participate in teaching activities where teachers provide them with a sense of security. The teaching material should be at the appropriate linguistic level and stimulate students to actively participate in the teaching process. They should be encouraged to recognize and reduce language anxiety within individual differences. Students can find creative ways to solve their problems by sharing the feeling of anxiety and discomfort with their peers.

Several directions for further research evolve from the findings. Future studies focusing on the relationship between language anxiety, learning strategies, gender, and personality could provide further support for the findings. In addition, more empirical studies and different kinds of instruments could shed some light on the way students learn.

\section{References}

Aida, Y. (1994). Examination of Horwitz, Horwitz, and Cope's construct of foreign language anxiety: The case of students of Japanese. The Modern Language Journal, 78(2), 155-168. https://doi.org/10.1111/j.1540-4781.1994.tb02026.x

Asmalı, M. (2017). Big Five Personality Traits and Test Anxiety among English as a Foreign Language Learners. Igdir University Journal of Social Sciences, 11, 1-21. 
Aydın, S., Yavuz, F., \& Yeşilyurt, S. (2006). Test anxiety in foreign language learning. Journal of Social Sciences Institute Balikesir University, 9(16), 145-160.

Chamorro, T., Ahmetoglu, G., \& Furnham, A. (2008). Little more than personality: Dispositional determinants of test anxiety (the Big Five, Core Self-evaluations, and Self-assessed Intelligence). Learning and Individual Differences, 18, 258-263. https://doi. org/10.1016/j.lindif.2007.09.002

Cheng, Y. S., Horwitz, E. K., \& Schallert, D. L. (1999). Language anxiety: Differentiating writing and speaking components, Language Learning, 49(3), 417-446. https://doi. org/10.1111/0023-8333.00095

Dewaele, J. M. (2002). Psychological and sociodemographic correlates of communicative anxiety in L2 and L3 production. International Journal of Bilingualism, 6(1), 23-38. https:// doi.org/10.1177/13670069020060010201

Dewaele, J.M. (2013). The link between foreign language classroom anxiety and psychoticism, extraversion, and neuroticism among adult bi- and multilinguals. The Modern Language Journal, 97(3), 670-684. https://doi.org/10.1111/j.1540-4781.2013.12036.x

El-Zahhar, N. E., \& Hocever, D. (1991). Cultural and sexual differences in test anxiety, trait anxiety, and arousability. Journal of Cross Cultural Psychology, 22(2), 238-249. https://doi. org/10.1177/0022022191222005

Goh, S. E., Dillon, D., \& Goh, S. Y. W. (2016). Predicting foreign language anxiety: trait emotional intelligence and Big-Five personality traits. In Proceedings of the Asia-Pacific English Language Teaching Conference (pp. 63-69), ELTC 2016: Asia-Pacific English Language Teaching Conference, 11-13 June 2016, Shanghai, China.

Goldberg, L. R. (1992). The Development of Markers for the Big-Five Factor Structure. Psychological Assessment, 4(1), 26-42. https://doi.org/10.1037/1040-3590.4.1.26

Goldberg, L. R. (2001). International Personality Item Pool. Retrieved from http://bit. $\underline{\mathrm{ly} / 1 \mathrm{AfXuFc}}$

Horwitz, M. B., Horwitz, E.K., \& Cope, J. (1986). Foreign language classroom anxiety. The Modern Language Journal, 70(2), 125-132. https://doi.org/10.1111/j.1540-4781.1986. tb05256.x

Horwitz, E. K., \& Young D. J. (1991). Language anxiety: From theory and research to classroom implications. Englewood Cliffs, NJ: Prentice Hall.

Khosravi, M., \& Bigdely, I. (2008). The relationship between personality factors and test anxiety among university students. Journal of Behavioral Sciences, 12(1), 13-24.

Leary, M. R. (1983). A brief version of the fear of negative evaluation scale. Personality and Social Psychology Bulletin, 9, 371-375. https://doi.org/10.1177/0146167283093007

Leary, M. R., Springer, C., Negel, L., Ansell, E., \& Evans, K. (1998). The causes, phenomenology, and consequences of hurt feelings. J Pers Soc Psychol, 74, 1225-1237. https://doi. org/10.1037/0022-3514.74.5.1225

Madsen, H. S. (1982). Determining the debilitative impact of test anxiety. Language Learning, 32, 133-143. https://doi.org/10.1111/j.1467-1770.1982.tb00522.x 
Šafranj and Zivlak: Effects of Big Five Personality Traits and Fear of Negative Evaluation on Foreign ...

McCroskey, J. C. (1977). Oral Communication Apprehension: A Summary of Recent Theory and Research. Human Communication Research, 4, 78-96. https://doi. org/10.1111/j.1468-2958.1977.tb00599.x

Maclntyre, P. D., \& Gardner, R. C. (1991). Methods and results in the study of anxiety and language learning: A review of the literature. Language Learning, 41, 85-117. https://doi. org/10.1111/j.1467-1770.1991.tb00677.x

McIlroy, D., Bunting, B., \& Adamson, G. (2000). An evaluation of the factor structure and predictive utility of a test anxiety scale with reference to students' past performance and personality indices. British Journal of Educational Psychology, 70, 17-32. https://doi. org/10.1348/000709900157949

Öz, H. (2014). Big Five Personality Traits and Willingness to Communicate among Foreign Language Learners in Turkey. Social Behavior and Personality: An International Journal, 42, 1473-1482. https://doi.org/10.2224/sbp.2014.42.9.1473

Poropat, A. E. (2009). A meta-analysis of the five-factor model of personality and academic performance. Psychological Bulletin, 135(2), 322-338. https://doi.org/10.1037/a0014996

Putwain, D. W. (2007). Test anxiety in UK schoolchildren: Prevalence and demographic patterns. British Journal of Educational Psychology, 77(3), 579-593. https://doi. org/10.1348/000709906X161704

Saito, Y., \& Samimy, K. K. (1996). Foreign language anxiety and language performance: A study of learner anxiety in beginning, intermediate, and advanced-level college students of Japanese. Foreign Language Annals, 29(2), 239-249. https://doi. org/10.1111/j.1944-9720.1996.tb02330.x

Sarason, I. G. (1984). Stress, anxiety, and cognitive interference: reactions to tests. Journal of Personality and Social Psychology, 46, 929-938. https://doi.org/10.1037/0022-3514.46.4.929

Sellers, V. D. (2000). Anxiety and reading comprehension in Spanish as a foreign language. Foreign Language Annals, 33(5), 512-520. https://doi.org/10.1111/j.1944-9720.2000. $\underline{\text { tb01995.x }}$

Schlenker, B. R. (1980). Impression management. Monterey, CA: Brooks/Cole. Google Scholar.

Schlenker, B. R., \& Leary, M. R. (1982). Audiences' reactions to self-enhancing, selfdenigrating, accurate, and modest self-presentations. Journal of Experimental Social Psychology, 18, 89-104. https://doi.org/10.1016/0022-1031(82)90083-X

Shohamy, E. (1982). Affective considerations in language teaching. Modern Language Journal, 66 (1), 13 -17. https://doi.org/10.1111/j.1540-4781.1982.tb01015.x

Spielberger, C. D. (1983). Manual for the State-Trait-Anxiety Inventory (STAI-form Y). Palo Alto, CA: Consulting Psychologists Press. https://doi.org/10.1037/t06496-000

Spielberger, C. D., Anton, W. D., \& Bedell, J. (1976). The nature and treatment of test anxiety. In M. Zuckermann, \& C. Spielberger (Eds.), Emotions and anxiety: New concepts, methods and applications (pp. 317-44). Hillsdale, NJ: Lawrence Erlbaum.

Toegel, G., \& Barsoux, J. L. (2012). How to become a better leader. MIT Sloan Management Review, 53(3), 51-60.

Tzoannopoulou, M. (2016). Foreign language anxiety and fear of negative evaluation in the Greek university classroom. Selected Papers of the 21st International Symposium on Theoretical and Applied Linguistics (ISTAL 21), 823-838. 
Verhoeven, L., \& Vermeer, A. (2002). Communicative competence and personality dimensions in first and second language learners. Applied Psycholinguistics, 23(3), 361374. https://doi.org/10.1017/S014271640200303X

Woodrow, L. (2006). Anxiety and speaking English as a second language. RELC Journal, 37(3), 308-328. https://doi.org/10.1177/0033688206071315

Zee, K. V., Thijs, M., \& Schakel, L. (2002). The relationship of emotional intelligence with academic intelligence and the Big Five. European Journal of Personality, 16(2), 103-125. https://doi.org/10.1002/per.434

\author{
Jelisaveta Šafranj \\ Department of Fundamental Sciences in Engineering, \\ Faculty of Technical Sciences, University of Novi Sad, \\ Trg Dositeja Obradovića 6, 21000 Novi Sad, Serbia \\ savetas@uns.ac.rs \\ Jelena Zivlak \\ Department of Fundamental Sciences in Engineering, \\ Faculty of Technical Sciences, University of Novi Sad, \\ Trg Dositeja Obradovića 6, 21000 Novi Sad, Serbia \\ zivlakjelena@uns.ac.rs
}

\title{
Appendix
}

\section{Appendix 1}

Pearson correlations among the variables in the research

\begin{tabular}{cccccccccccccc}
\hline & 1 & 2 & 3 & 4 & 5 & 6 & 7 & 8 & 9 & 10 & 11 & 12 & 13 \\
\hline 1 & & & & & & & & & & & & & \\
2 & -.03 & & & & & & & & & & & & \\
3 & $.36^{* *}$ & $.20^{* *}$ & & & & & & & & & & & \\
4 & $.17^{* *}$ & $.17^{* *}$ & -.06 & & & & & & & & & & \\
5 & $.28^{* *}$ & $.29^{* *}$ & $.27^{* *}$ & $.14^{*}$ & & & & & & & & & \\
6 & -.08 & -.05 & -.02 & $-.33^{* *}$ & $-.31^{* *}$ & & & & & & & & \\
7 & $-.12^{*}$ & -.02 & -.04 & $-.31^{* *}$ & $-.31^{* *}$ & $.96^{* *}$ & & & & & & & \\
8 & -.06 & -.02 & .01 & $-.30^{* *}$ & $-.26^{* *}$ & $.90^{* *}$ & $.82^{* *}$ & & & & & & \\
9 & -.06 & -.09 & -.03 & $-.33^{* *}$ & $-.31^{* *}$ & $.96^{* *}$ & $.87^{* *}$ & $.80^{* *}$ & & & & & \\
10 & .12 & -.05 & .06 & $-.38^{* *}$ & $-.19^{* *}$ & $.37^{* *}$ & $.34^{* *}$ & $.36^{* *}$ & $.36^{* *}$ & & & & \\
11 & .05 & .03 & .03 & .07 & $.30^{* *}$ & $-.58^{* *}$ & $-.57^{* *}$ & $-.50^{* *}$ & $-.57^{* *}$ & $-.21^{* *}$ & & & \\
12 & .07 & .00 & $.15^{* *}$ & -.08 & $-.27^{* *}$ & $.45^{* *}$ & $.46^{* *}$ & $.38^{* *}$ & $.42^{* *}$ & $.14^{*}$ & $-.57^{* *}$ & & \\
13 & .04 & .10 & .04 & .05 & $.29^{* *}$ & $-.59^{* *}$ & $-.58^{* *}$ & $-.53^{* *}$ & $-.56^{* *}$ & $-.21^{* *}$ & $.78^{* *}$ & $-.54^{* *}$ & \\
14 & .03 & -.02 & .06 & -.01 & $.21^{* *}$ & -.31 & -.30 & -.28 & -.30 & -.12 & $.39^{* *}$ & $-.33^{* *}$ & $.36^{* *}$ \\
\hline
\end{tabular}

Note. 1 - Extraversion. 2 - Conscientiousness. 3 - Agreeableness. 4 - Emotional stability. 5 - Intellect. 6 - Language anxiety (total score). 7 - Communication apprehension. 8 - Fear of feedback by peers and teachers. 9 - Fear of language tests. 10 - Fear of negative evaluation. 11 - English comprehension (self-assessment). 12 - Reading frequency. 13 - Verbal fluency (self-assessment). 14 - Overall length of language learning. ${ }^{* *} p<.01,{ }^{*} p<.05$ 


\section{Utjecaj pet velikih osobina i straha od negativne evaluacije na anksioznost pri učenju stranog jezika}

\section{Sažetak}

Predmet istraživanja su osobine prema modelu pet velikih i strah od negativne evaluacije kao determinante jezične anksioznosti. Problem istraživanja odnosi se na način na koji je anksioznost pri učenju stranog jezika uvjetovana određenim osobinama primjenom modela velikih pet na osnovi statistički kontroliranih varijabli koje uključuju samoprocjenu vladanja jezikom, fluentnost, učestalost čitanja tekstova na engleskom jeziku i dužine učenja jezika, imajući u vidu da je taj problem $u$ dosadašnjim istraživanjima nedovoljno ispitivan. Istraživanje je provedeno na 296 studenata s pomoću tri upitnika: Medunarodnog repozitorija stavki za procjenu osobnosti (Goldberg, 2001), Skale za mjerenje anksioznosti u nastavi stranog jezika (Horwitz, Horwitz, i Cope, 1986) i skraćene verzije Skale straha od negativne evaluacije (Leary, 1983) prevedene na srpski jezik i tri dodatna pitanja o samoprocjeni studenata u smislu razumijevanja engleskog jezika, učestalosti čitanja engleskih tekstova $i$ verbalne fluentnosti. Cilj je bio ispitati doprinos osobina u predvidanju jezične anksioznosti nakon što se statistički kontroliraju navedene samoprocjene, dužina učenja engleskog jezika i provjeri nezavisni prediktivni doprinos straha od negativne evaluacije u odnosu na osobine i samoprocjenu studenata. Rezultati ukazuju na to da niska razina emocionalne stabilnosti predstavlja pouzdan prediktor visokog stupnja opće anksioznosti i njezinih tipova definiranih na osnovi brojčanih vrijednosti na podskalama. Studenti skloni strahu od negativne evaluacije skloniji su anksioznosti. S obzirom na umjerenu povezanost između straha od negativne evaluacije i straha od reakcije vršnjaka i nastavnika može se zaključiti da anksioznost nije posljedica isključivo općeg straha od negativne evaluacije. Također, visok stupanj savjesnosti predstavlja specifičan prediktor visokog stupnja straha od komunikacije.

Ključne riječi: anksioznost; evaluacija; prediktori; reakcija vršnjaka i nastavnika; učenje stranog jezika

\section{Uvod}

Anksioznost pri učenju stranog jezika ima velik utjecaj na učenje i predstavlja reakciju koju učenici doživljavaju kao prijetnju njihovu osjećaju sigurnosti ili 
samopouzdanju (Spielberger, Anton, i Bedell, 1976). Tu anksioznost možemo opisati kao subjektivan osjećaj napetosti, straha, nervoze i zabrinutosti u procesu učenja, odnosno kao strah koji se doživljava kada se od nas traži da upotrebljavamo strani jezik kojim ne vladamo u potpunosti. Istodobno, radi se o neugodnom osjećaju tjeskobe praćenom jednom ili više tjelesnih reakcija, npr. neugodnim osjećajem u trbuhu, pritiskom u grudima, udaranjem srca, ubrzanim disanjem ili glavoboljom. Sve veći broj istraživanja koja se bave anksioznošću pri učenju jezika ima za posljedicu klasificiranje tog fenomena pa tako u literaturi imamo anksioznost kao osobinu, stanje anksioznosti i anksioznost u određenim situacijama (MacIntyre i Gardner, 1991).

Anksioznost kao osobina odnosi se na anksioznost u svakoj situaciji (Spielberger, 1983) i definira se kao permanentna predispozicija.

Za razliku od relativno stabilnog emocionalnog stanja koje se javlja prilikom opisivanja anksioznosti kao osobine, stanje anksioznosti predstavlja trenutnu osobinu koja nije uvijek prisutna, npr. prije polaganja važnog ispit (MacIntyre i Gardner, 1991). Anksioznost u određenim situacijama predstavlja treću vrstu anksioznosti, i definira se kao osjećaj nelagode kod ispitanika u određenim trenucima, kao reakcija na danu situaciju (Woodrow, 2006). Taj tip anksioznosti u velikoj mjeri olakšava ispitivanje anksioznosti pri učenju jezika, budući da omogućuje razmatranje različitih čimbenika koji dovode do tog stanja.

O tome kako dolazi do jezične anksioznosti, postoje brojne teorije. Horwitz i Young (1991) smatraju da se ona može promatrati kao manifestacija drugih oblika anksioznosti, kao što su strah od usmene komunikacije, strah od negativne društvene evaluacije i anksioznosti pri testiranju (jezičnog) znanja.

McCroskey (1977) definira strah od usmene komunikacije kao individualni vid anksioznosti povezan sa stvarnom ili očekivanom konverzacijom s nekom drugom osobom. Horwitz i suradnici (Horwitz i sur., 1986) ugrađuju taj koncept straha od usmene komunikacije u svoj koncept jezične anksioznosti.

Strah od reakcije vršnjaka i nastavnika jedan je širi koncept, budući da ne ovisi o situaciji. MacIntyre i Gardner (1991) vjeruju da kada učenici nisu sigurni što govore, oni strahuju od gubitka imidža u javnosti i počinju sumnjati u svoju sposobnost da ostave pozitivan dojam. Navedeni autori tvrde da zbog tog straha učenici često reagiraju pasivno, odbijajući sudjelovati u aktivnostima koje mogu utjecati na poboljšanje jezičnih vještina. U nekim slučajevima učenici namjerno izostaju sa sati stranog jezika kako bi izbjegli neugodne situacije, zbog kojih se osjećaju kao da zaostaju za svojim vršnjacima (MacIntyre i Gardner, 1991; Tzoannopoulou, 2016).

Anksioznost pri testiranju (jezičnog) znanja primjećuje se kod učenika koji su slabo riješili test i tada razvijaju negativan stereotip o testovima i ne shvaćaju način njihova ocjenjivanja (Sarason, 1984). Učenici koji su bili u sličnoj situaciji na drugim predmetima često nesvjesno prenose ta iskustva i na predmet stranog jezika. Često pred sebe postavljaju nerealne zahtjeve i smatraju da je sve osim savršenog rezultata 
neuspjeh (Horwitz i sur., 1986). Ona se javlja kao posljedica više čimbenika, kao što su stavovi učenika o učenja jezika i njihova sposobnost učenja (Shohamy, 1982), vremensko ograničenje, osobne varijable, kao što su spol, starost, obrazovanje i ekonomski status roditelja (Madsen, 1982; Putwain, 2007).

Chamorro, Ahmetoglu i Furnham (2008) ispitivali su dispozicijske determinante anksioznosti pri testiranju znanja kod američkih i britanskih studenata. Samoprocijenjena inteligencija, osobnost i samoevaluacija sudionika navedeni su kao determinante anksioznosti pri testiranju znanja. Rezultati su pokazali da je anksioznost pri testiranju znanja u pozitivnoj korelaciji s neuroticizmom i samoevaluacijom ispitanika, a u negativnoj s ugodnošću, otvorenošću i savjesnošću. Osim toga, rezultati ukazuju na snažnu izravnu vezu između 'neuroticizma' i anksioznosti pri testiranju znanja, kao i na umjeren utjecaj ekstroverzije na anksioznost pri testiranju.

Aydin, Yavuz i Yeşilyurt (2006) proučavali su anksioznost pri testiranju znanja i njezin utjecaj na učenje stranog jezika na sveučilištu u Turskoj. Rezultati su pokazali da se u čimbenike koji predviđaju anksioznost pri testiranju ubrajaju nizak stupanj poznavanja engleskog jezika, stavovi studenata u vezi s učenjem jezika, negativni stavovi nastavnika prema testu, očekivanja roditelja i strah od negativne evaluacije. Osim toga, pokazalo se da anksioznost pri testiranju znanja izaziva fizičke i psihičke probleme tako što utječe na koncentraciju i motivaciju te umnožava greške pri učenju jezika. El-Zahhar i Hocever (1991) su primijetili da u Brazilu, SAD-u i arapskim zemljama anksioznost pri testiranju potječe od ekstremnih posljedica po postignuća na ispitima, pogotovo u srednjim školama.

Horwitz i sur. (1986) dali su svoj doprinos tom području izradom Skale za mjerenje anksioznosti u nastavi stranog jezika. Taj instrument namijenjen je mjerenju stupnja anksioznosti specifične za učenje stranog jezika i zahvaljujući njegovoj visokoj kvaliteti i pouzdanosti veoma se često koristi u anketama.

\section{Velikih pet osobina i strah od negativne evaluacije}

Neke osobine važne su determinante anksioznosti pri učenju jezika zbog čega je model velikih pet veoma važan za ovo istraživanje. Taj model nastao je tridesetih godina XX. stoljeća, ali je u širu upotrebu ušao tek osamdesetih godina prošlog stoljeća (Goldberg, 1992). U tom empirijskom modelu predloženo je pet osnovnih dimenzija kojima su se psiholozi služili da bi opisali čovjekovu osobnost. Te su dimenzije: otvorenost prema iskustvu, savjesnost, ekstrovertnost, ugodnost i neuroticizam. Svaki od predloženih čimbenika sastoji se od više povezanih i preciznijih primarnih osobina:

- Otvorenost prema iskustvu (inventivan/radoznao naspram dosljedan/oprezan). Pozitivan odnos prema avanturi, umjetnosti, radoznalosti, neobičnim idejama, emocijama i brojnim drugim doživljajima. Otvorenost ukazuje na sklonost inovacijama i raznolikosti, kreativnosti i određenom stupnju intelektualne radoznalosti. Visok stupanj otvorenosti može se shvatiti kao nepredvidljivost ili nedostatak usredotočenosti, a osobe s niskim stupnjem otvorenosti pokušavaju naći 
zadovoljstvo putem onog što im je poznato. (Toegel i Barsoux, 2012) Otvorenost prema iskustvu ponekad je povezana s intelektualnim sposobnostima ili intelektom.

- Savjesnost (djelotvoran/organiziran u odnosu na aljkav/nemaran). Savjesne su osobe pouzdane i dobro organizirane, predane su poslu, pokazuju samodisciplinu, važna su im postignuća, prednost daju planiranom radu, a ne spontanom ponašanju. Visok stupanj savjesnosti doživljava se kao tvrdoglavost i opsesivnost, a nizak stupanj vezuje se uz fleksibilnost i spontanost (Toegel i Barsoux, 2012).

- Ekstrovertnost (društven/energičan naspram usamljen/rezerviran). Afirmativnost, impulzivnost, energičnost, društvenost, sklonost u traženju stimulacija u društvu drugih ljudi, pričljivost. Visok stupanj ekstrovertnosti doživljava se kao autoritarnost i traženje pažnje, a nizak stupanj ukazuje na povučenu, promišljenu osobu. (Toegel i Barsoux, 2012)

- Ugodnost (prijateljski/suosjećajan naspram zahtjevan/bezosjećajan). Sklonost empatiji i suradnji umjesto suprotstavljanja drugima. Ugodna osoba je po prirodi pouzdana, spremna pomoći i ima dobru narav. Visok stupanj ugodnosti često se doživljava kao naivnost ili poniznost, a nizak stupanj vezuje se uz natjecateljski raspoložene, zahtjevne osobe (Toegel i Barsoux, 2012).

- Neuroticizam (osjetljiv/nervozan naspram stabilan/pouzdan). Sklonost lakom podnošenju neugodnih emocija, kao što su iritacija, depresija, anksioznost, osjetljivost. Neuroticizam se također odnosi na kontroliranje impulsa i određen stupanj emocionalne stabilnosti, kako se često i naziva. Osoba s visokim stupnjem potrebe za stabilnošću je staložena osoba, a nizak stupanj ukazuje na osobu koja lako pada u vatru (Toegel i Barsoux, 2012).

Brojni istraživači ispitali su model pet velikih osobina u odnosu na različite konstrukte za učenje stranog jezika, kao što su komunikativna kompetentnost (Verhoeven i Vermeer, 2002), emocionalna i akademska inteligencija (Zee, Thijs i Schakel, 2002), spremnost na komunikaciju (Öz, 2014) i strategije učenja jezika (Asmalı, 2014). Međutim, malo je provedenih istraživanja čiji je cilj otkriti vezu između pet velikih osobina i anksioznosti pri učenju stranih jezika.

U istraživanju koje su proveli McIlroy i sur. (McIlroy, Bunting i Adamson, 2000) ispitivana je anksioznost pri testiranju da bi se odredilo je li pogodna za četverofaktorsku strukturu (napetost, zabrinutost, tjelesni simptomi $i$ irelevantne misli pri testiranju), kao i njezina povezanost $s$ akademskim učinkom i osobnošću. Rezultati su pokazali da je samodjelotvornost u očitoj i postojanoj vezi s četiri čimbenika anksioznosti pri testiranju. Također je otkrivena veza između 'savjesnosti' i čimbenika anksioznosti pri testiranju.

Khosravi i Bigdely (2008) ispitivali su neke od čimbenika osobnosti kao što su ekstrovertnost, introvertnost i neuroticizam te njihovu interakciju s anksioznošću pri testiranju znanja. Rezultati su pokazali da je anksioznost pri testiranju u pozitivnoj korelaciji s neuroticizmom. Između anksioznosti pri testiranju te ekstrovertnosti i intravertnosti nisu pronađene značajne korelacije. 
Asmali (2017) je ispitivao pet velikih osobina i anksioznost pri testiranju kod učenika engleskog jezika u Turskoj. Studija ukazuje na negativnu korelaciju između anksioznosti pri testiranju i osobina emocionalna stabilnost, imaginacija i ekstrovertnost. Regresivnim analizama je potvrđeno da su emocionalna stabilnost i imaginacija prediktori anksioznosti pri testiranju.

U novijoj studiji (Tzoannopoulou, 2016) na skupini grčkih studenata ispitan je odnos između jezične anksioznosti i straha od negativne evaluacije. Dobiveni rezultati pokazali su da spol i uspješnost ispitanika znatno utječu na anksioznost i strah od negativne evaluacije. Studentice sa srednje i više razine nastave bile su više anksiozne i sklonije strahu od negativne evaluacije od studenata iste razine.

Dakle, naše istraživanje, uz ostalo, treba popuniti prazninu u literaturi u pogledu odnosa između pet velikih osobina i anksioznosti pri učenju stranog jezika na sveučilištu. Osim toga, u istraživanje je uključen i strah od negativne evaluacije i testiran je njegov doprinos u predviđanju anksioznosti neovisno o osobinama.

Strah od negativne evaluacije predstavlja jedan od vidova društvene anksioznosti (Schlenker i Leary, 1982) i odnosi se na stupanj u kojem pojedinci strahuju da će biti negativno ocijenjeni. Strah može nastupiti kada pojedinac razmišlja o evaluaciji koja slijedi ili koja je u tijeku, i potječe iz potrebe za priznanjem i željom da se izbjegne osuda. Ljudi s izraženim strahom sumnjičavi su u pogledu svojih sposobnosti i boje se da će kod drugih izazvati osećaj da nisu poželjni (Schlenker i Leary, 1982). Strah od negativne evaluacije je negativno povezan sa samopoštovanjem, a pozitivno $s$ anksioznošću u određenoj situaciji i stidljivošću. Ljudi koji više strahuju od negativne evaluacije imaju veću motivaciju za stjecanje priznanja od društva i više se boje negativne reakcije nego ljudi koji manje strahuju (Leary, Springer, Negel, Ansell, i Evans, 1998).

U prijašnjim istraživanjima zaključeno je da su sudionici manje anksiozni kada manje strahuju od negativne evaluacije (Leary i sur., 1998; Schlenker i Leary, 1982). Otkrivene su negativne korelacije i između anksioznosti pri testiranju znanja i osobina emocionalna stabilnost, imaginacija i ekstrovertnost (Khosravi i Bigdely, 2008). Dakle, emocionalna stabilnost i imaginacija identificirane su kao osobine koje nagoviještaju anksioznost pri testiranju znanja.

Osobine predstavljaju relativno trajne i nepromjenjive karakteristike pojedinaca kada se kod predikcije očekuju određene regularnosti ili kad se ustanovi da neki pojedinci imaju specifičnu predispoziciju za anksioznost pri učenju stranog jezika. $U$ tom slučaju uvjeti u kojima oni izlaze na ispit iz stranog jezika mogu se modificirati ili se mogu obaviti neke dodatne intervencije kako bi učenici mogli naučiti kako da se suoče s anksioznošću pri testiranju znanja i kako da se smire i ohrabre. Osim toga, ova studija treba pružiti i neke dokaze o pitanju anksioznosti pri učenju stranog jezika i straha od negativne evaluacije, područja kojima je posvećena nedovoljna pažnja u fakultetskom kontekstu. Nekoliko pravaca u usmjeravanju na odnos između straha od negativne evaluacije, anksioznosti pri učenju stranog jezika, strategija učenja i osobnosti može dovesti do daljnjeg napretka i u učenju jezika. 


\section{Predmet i cilj istraživanja}

Predmet ovog istraživanja su osobine (operacionalizirane preko modela pet velikih) i strah od negativne evaluacije kao potencijalne determinante jezične anksioznosti. Kako bi se dobila što jasnija slika o prirodi odnosa navedenih varijabli, statistički su kontrolirane sljedeće, dodatne varijable: samoprocjena vladanja jezikom, fluentnost, učestalost čitanja tekstova na engleskom jeziku i dužina učenja jezika. Dakle, cilj istraživanja bio je ispitati na koji način osobine predviđaju jezičnu anksioznost nakon što se otkloni utjecaj potencijalno konfundirajućih varijabli. Dodatni je cilj bio ispitati postoji li nezavisan prediktivan doprinos straha od negativne evaluacije u kontekstu jezične anksioznosti, uz prediktivan doprinos osobina. Testirane su sljedeće hipoteze:

Hipoteza 1. Bolja samoprocjena vladanja jezikom, fluentnost, učestalost čitanja tekstova na engleskom jeziku i duže učenje jezika predstavljaju negativne prediktore jezične anksioznosti;

Hipoteza 2. Viša emocionalna stabilnost, intelekt, ekstroverzija značajno predviđaju niži stupanj jezične anskioznosti, a viša savjesnost predviđa viši stupanj jezične anksioznosti;

Hipoteza 3. Viši stupanj straha od negativne evaluacije predviđa višu jezičnu anksioznost uz osobine ili neovisno o njima.

\section{Metoda istraživanja Uzorak}

Provedeno je eksplorativno istraživanje na prigodnom uzorku od 296 studenata inženjerstva s Fakulteta tehničkih znanosti Sveučilišta u Novom Sadu (Tablica 1) koji su pohađali predmet Engleski jezik za posebne namjene u trajanju od jednog semestra. Prosječna starost studenata bila je 20,6 godina ( $S D=1,4)$, a po spolu je podjela bila podjednaka ( $48 \%$ muških). Minimalno trajanje učenja jezika među ispitanicima bilo je 2 godine, a maksimalno $18(\mathrm{M}=12, \mathrm{SD}=2,37)$. Studenti energetskog inženjerstva pohađali su drugu godinu sveučilišnog obrazovanja, a ostali studenti studija građevinarstva, strojarstva i industrijskog upravljanja pohađali su prvu godinu studija.

Tablica 1

\section{Instrumenti}

Skala za mjerenje anksioznosti u nastavi stranog jezika (FLCAS; Horwitz i sur. 1986), prevedena i prilagođena srpskom jeziku. FLCAS predstavlja instrument za mjerenje anksioznosti pri učenju stranog jezika u kontekstu nastave, a koja djeluje po principu izvještavanja samih studenata. Sastoji se od 33 stavke s Likertovom skalom od pet točaka ( 1 - uopće se ne slažem, 5 - potpuno se slažem). Osim ukupne vrijednosti ( $\alpha=$ ,94), mogu se koristiti i tri vrijednosti ostvarene na podskalama Strah od komunikacije (11 stavki, $\alpha=, 86)$ primjer stavke 9 - Počnem paničariti kada trebam govoriti na satu stranog jezika, Strah od reakcije vršnjaka i nastavnika $(7$ stavki, $\alpha=, 81)$ primjer stavke 
7 - Mislim da su drugi studenti bolji u učenju stranog jezika od mene i Strah od testova znanja (15 stavki, $\alpha=, 86)$ primjer stavke 21 - Što više učim za ispit stranog jezika, to sam zbunjeniji. Vrijednosti na opisanim dimenzijama u kontekstu ovog istraživanja imaju ulogu kriterijskih varijabli.

Goldbergovih Velikih pet osobina ličnosti iz Medunarodnog repozitorija stavki za procjenu osobnosti (IPIP; Goldberg, 2001). Velikih pet osobina procijenjene su na osnovi Goldbergovih stavki iz javne domene koje su prevedene na srpski jezik. Svaka je osobina procijenjena primjenom po 10 stavki na osnovi Likertove skale s pet točaka ( 1 - uopće se ne slažem, 5 - potpuno se slažem). Pouzdanost skala bila je sljedeća: ekstrovertnost $\alpha=, 75$, savjesnost $\alpha=, 73$, ugodnost $\alpha=, 77$, emocionalna stabilnost/ neuroticizam $\alpha=, 86 \mathrm{i}$ intelekt $\alpha=, 71$. Osobine operacionalizirane s pomoću tog instrumenta imaju status prediktorskih varijabli.

Strah od negativne evaluacije (FNE; Leary, 1983). Strah od negativne evaluacije predstavlja skraćenu inačicu mjerila straha od negativne evaluacije kao jednog od aspekata društvene anksioznosti. $U$ pitanju je skala od 12 stavki s Likertovom skalom od pet točaka ( 0 - uopće se ne slažem, 5- potpuno se slažem). Pouzdanost srpske inačice koja je primijenjena na ovom uzorku je $\alpha=, 81$. Strah od negativne evaluacije predstavlja jedan od prediktora u testiranim modelima.

Postavljena su još četiri pitanja - tri koja se odnose na samoprocjene studenata u pogledu razumijevanja engleskog jezika (Kako ocjenjujete vlastite mogućnosti razumijevanja engleskog jezika?), učestalosti čitanja tekstova na engleskom (Koliko često čitate tekstove na engleskom jeziku?), i verbalne fluentnosti (Kako ocjenjujete vlastitu verbalnu fluentnost na engleskom jeziku?) i jedno koje se odnosi na ukupnu dužinu trajanja učenja engleskog jezika tijekom života. Prva tri pitanja studenti su ocijenili na Likertovoj skali od sedam točaka ( 1 - loše, 7 - izvanredno). Opisane procjene koristile su se kao kontrolne varijable, odnosno kovarijati.

\section{Rezultati i analize}

Deskriptivna statistika za varijable koje su se koristile u ovom istraživanju izračunata je i prikazana u Tablici 2. Prema vrijednosti zakrivljenosti i spljoštenosti distribucije, može se reći da sve vrijednosti gotovo prate normalnu distribuciju.

Tablica 2

S ciljem pronalaženja odgovora na pitanja iz istraživanja, testirano je nekoliko hijerarhijskih višestrukih regresijskih modela. $U$ prvom su koraku u svaki model unijete kontrolne varijable - samoprocijenjena razina razumijevanja engleskog, verbalna fluentnost i učestalost čitanja na engleskom, kao i ukupna dužina trajanja učenja engleskog jezika. U drugom koraku unijeto je pet dimenzija ličnosti (ekstroverzija, savjesnost, ugodnost, emocionalna stabilnost $\mathrm{i}$ intelekt) kao prediktora, a u posljednjem koraku unesen je Strah od negativne evaluacije. Sljedeće varijable definirane su kao kriteriji: ukupna vrijednost na upitniku Skala mjerenja anksioznosti u nastavi stranog 
jezika i vrijednosti dobivene upotrebom podskala (Strah od komunikacije, Strah od reakcije vršnjaka i nastavnika i Strah od jezičnih testova). Raspodjelom prediktorskih varijabli u opisana tri koraka dobiva se informacija o tome koliko varijance kriterija može biti objašnjeno samo kontrolnim varijablama, koji postotak varijance povrh njih objašnjavaju osobine ličnosti i, na kraju, pridonosi li i koliko objašnjenju kriterija strah od negativne evaluacije neovisno o svim preostalim varijablama u modelu.

\section{Tablica 3}

Unošenjem kontrolnih varijabli u prvom koraku objašnjeno je 40\% varijance. Unošenjem vrijednosti na dimenzijama osobnosti i strahu od negativne evaluacije objašnjeno je još $10 \%$, odnosno $1 \%$ varijance. Modelom je objašnjeno ukupno $51 \%$ varijance kriterija. Svaki korak u modelu ocijenjen je kao statistički značajan (Tablica 3).

Rezultati dobiveni u posljednjem koraku modela pokazuju da od kontrolnih varijabli samo Verbalna fluentnost predstavlja značajan prediktor stupnja anksioznosti pri učenju jezika. Nakon provjere tih varijabli, emocionalna stabilnost i strah od negativne evaluacije ocijenjeni su kao nezavisni, značajni prediktori - niža vrijednost na emocionalnoj stabilnosti i viša vrijednost na strahu od negativne evaluacije nagoviještali su veće vrijednosti na Anksioznosti pri učenju stranog jezika (Tablica 3).

\section{Tablica 4}

Kontrolne varijable u prvom koraku modela objasnile su 39\% varijance. Vrijednosti na dimenzijama osobnosti i strahu od negativne evaluacije objasnile su još $9 \%$, odnosno $1 \%$ varijance kriterijske varijable. Model je objasnio ukupno $48 \%$ kriterija. Svaki korak u modelu ocijenjen je kao statistički značajan (Tablica 4).

U sljedećem testiranom modelu, u kojem se strah od komunikacije koristio kao kriterijska varijabla (Tablica 4), sve kontrolne varijable ocijenjene su kao značajni prediktori. Dodatna varijanca objašnjena je savjesnošću na taj način da će oni $s$ većom brojčanom vrijednošću na ovoj osobini imati veću vrijednost i na strahu od komunikacije. Kod emocionalne stabilnosti dobiven je suprotan rezultat: veća vrijednost na toj osobini nagovijestila je nižu vrijednost na Strahu od komunikacije. Strah od negativne evaluacije ocijenjen je kao značajan prediktor, neovisno o svim ostalim varijablama.

\section{Tablica 5}

Ovaj model (Tablica 5) ukupno je objasnio $41 \%$ varijance. Kontrolne varijance objasnile su 30\%, a vrijednosti na dimenzijama osobnosti i strahu od negativne evaluacije objasnile su još $9 \%$, odnosno $2 \%$ varijance kriterijske varijable. Ti relativni udjeli ocijenjeni su kao statistički značajni.

Rezultati prikazani u Tablici 5 pokazuju da samoprocijenjena verbalna fluentnost predstavlja značajan prediktor straha od reakcije vršnjaka i nastavnika (oni koji sebe ocjenjuju kao manje fluentni skloni su većoj anksioznosti pri učenju stranog jezika). 
Ostali značajni prediktori bili su emocionalna stabilnost (negativna relacija) i strah od negativne evaluacije.

\section{Tablica 6}

U Tablici 6 prikazani su rezultati za model u kojem se strah od jezičnih testova koristio kao kriterijska varijabla. Svaki korak u tom modelu bio je statistički značajan i objasnio je ukupno 48\% kriterijske varijance. Nakon dodavanja kontrolnih varijabli, dimenzije osobnosti objasnile su dodatnih $11 \%$ varijance, a strah od negativne evaluacije objasnio je još $1 \%$, neovisno o svim drugim varijablama.

Prema rezultatima prikazanim u Tablici 6, u posljednjem koraku testiranog modela razumijevanje engleskog, verbalna fluentnost, emocionalna stabilnost i strah od negativne evaluacije ocijenjeni su kao značajni prediktori.

Nakon provjere samoprocijenjenog razumijevanja engleskog, verbalne fluentnosti, učestalosti čitanja tekstova na engleskom i dužine učenja engleskog jezika, dobiva se da su emocionalna stabilnost i strah od negativne evaluacije konzistentni prediktori za sve kriterije - ukupne vrijednosti na FLCAS i vrijednosti na podskalama, kao što su strah od komunikacije, strah od reakcije vršnjaka i nastavnika i strah od jezičnih testova, i to u očekivanom smjeru. U slučaju kada se strah od komunikacije koristio kao kriterij, zabilježen je još jedan značajan prediktor - savjesnost.

\section{Rasprava}

Osnovni cilj ove studije bio je testirati prediktivnu moć osobina, definiranih primjenom petofaktorskog modela kada su vrijednosti na Skali anksioznosti pri učenju stranog jezika (ukupna vrijednost koja ukazuje na opću razinu anksioznosti pri učenju stranog jezika i vrijednost na podskalama - strah od komunikacije, strah od reakcije vršnjaka i nastavnika i strah od jezičnih testova) postavljene kao kriterijske varijable. S tom svrhom koristile su se stavke iz Goldbergova Međunarodnog repozitorija stavki za procjenu osobnosti (IPIP), kao i indikatori pet velikih pet osobina: ekstrovertnost, savjesnost, ugodnost, emocionalna stabilnost $i$ intelekt. Prije unošenja tih varijabli u model, najprije su, kao kontrolne varijable, unesene vrijednosti samoprocjene studenata u pogledu razumijevanja engleskog, verbalne fluentnosti i učestalosti čitanja tekstova na engleskom, kao i dužina trajanja učenja jezika. Imajući u vidu sve dobivene rezultate, može se utvrditi da su hipoteze djelomično potvrđene. Kada su u pitanju varijable koje su u istraživanje uključene radi izvjesne statističke kontrole, prva je hipoteza djelomično potvrđena. Samoprocjena verbalne fluentnosti jedina se pokazala kao negativan prediktor i ukupne vrijednosti na skali jezične anksioznosti i vrijednosti na subdimenzijama. Samoprocjena razumijevanja engleskog jezika pokazala se kao značajan prediktor straha od komunikacije i straha od jezičnih testova. Učestalost čitanja tekstova na engleskom jeziku pokazala se kao značajan prediktor jedino straha od komunikacije, i to suprotnog smjera od očekivanog. Na kraju, dužina trajanja učenja engleskog jezika ne pridonosi predikciji stupnja jezične anksioznosti, bilo da se radi o 
ukupnoj vrijednosti bilo da se radi o poddomenama. S obzirom na te rezultate može se ponuditi nekoliko objašnjenja. Koliko je netko siguran u svoju razinu razumijevanja engleskog jezika, čini se da se posebno odnosi samo na strah od komunikacije i strah od jezičnih testova jer takve domene odražavaju situacije kada student treba izravno pokazati svoje znanje. Osobina tih situacija može izazvati anksioznost zbog drugih razloga koji se razlikuju od očekivanih negativnih povratnih informacija. S druge strane, rezultati sugeriraju da oni koji češće čitaju, također pokazuju višu razinu straha od komunikacije. Može se pretpostaviti da oni koji puno čitaju imaju bogat rječnik, no kada je riječ o izravnoj komunikaciji, možda su zabrinuti jer nisu sigurni znaju li pravilno izgovoriti riječi koje su naučili čitajući. Također, možda se može objasniti i drugim karakteristikama osobnosti kao što su introverzija ili tendencije društvene anksioznosti. Oni koji su više posvećeni čitanju možda su i oni koji nisu uspješni u verbalnoj komunikaciji. Na kraju, oni koji češće čitaju, možda u isto vrijeme imaju manje iskustva u stvarnoj komunikaciji prakticiranja jezika, što dovodi do veće anksioznosti u tom aspektu demonstracije jezičnog znanja.

Uzimajući u obzir kontrolne varijable, nizak stupanj emocionalne stabilnosti predstavlja pouzdan prediktor visoke razine opće anksioznosti pri učenju stranog jezika i njezinih tipova definiranih putem vrijednosti na podskalama. Taj rezultat u skladu je s rezultatima prijašnjih studija u vezi s anksioznošću u učenju stranog jezika i u skladu s drugom hipotezom. Također, treba imati na umu da rezultati istraživanja (Toegel i Barsoux, 2012) pokazuju da su osobe s niskim stupnjem emocionalne stabilnosti općenito sklonije negativnim emocionalnim reakcijama i tumačenju informacija na osnovi negativnih predrasuda. Studenti s niskim stupnjem emocionalne stabilnosti vjerojatno su skloni više se brinuti zbog svog uspjeha u učenju jezika i očekivati negativan ishod, usredotočujući se na ono u čemu mogu pogriješiti, zbog čega nastaje stanje anksioznosti u situaciji kada trebaju pokazati svoje znanje iz stranog jezika. U pogledu relacija intelekta i ekstroverzije s jedne i jezične anksioznosti s druge strane, druga hipoteza nije potvrđena budući da rezultati sugeriraju da oni nisu značajni prediktori nižih razina anksioznosti.

Testirana je i nezavisna prediktivna moć straha od negativne evaluacije. Rezultati ukazuju na to da su studenti skloni strahu od negativne evaluacije također više skloni anksioznosti, što je u skladu s trećom hipotezom. S obzirom na umjereni odnos između tih konstrukata (posebno između straha od negativne evaluacije i straha od reakcije vršnjaka i nastavnika), može se zaključiti da se anksioznost ne može pripisati samo općem strahu od negativne evaluacije u društvenom kontekstu. Da pojasnimo, studenti pokazuju različite razine anksioznosti učenja jezika bez obzira na njihovo tumačenje situacije kao potencijalnog izvora negativne evaluacije.

Rezultati koji se tiču prediktivnog doprinosa savjesnosti u skladu su s drugom hipotezom jedino u kontekstu straha od komunikacije. Čini se da su savjesnije osobe sklonije toj vrsti jezične anksioznosti. Isto se tako čini da se savjesnije osobe više brinu zbog dojma koji na druge ostavljaju, štoviše, njima je važno da pokažu 
da su uložile određeni napor te da su vrijedno i intenzivno radile, što dovodi do povećane anksioznosti, posebno ako procijene da se nisu adekvatno pripremile, a imaju priliku pokazati svoje znanje pred razredom. Također, činjenica da će putem verbalne interakcije trenutačno dobiti povratnu reakciju može predstavljati baš ono na što su savjesne osobe osjetljive. Budući da je taj rezultat dobiven samo u slučaju kada su se koristile vrijednosti na podskalama, možda bi bilo svrsishodnije i informativnije koristiti se vrijednostima s podskala nego ukupnim vrijednostima. Da bi se ta pretpostavka potvrdila, potrebno je obaviti validaciju faktorske strukture srpskog prijevoda Skale anksioznosti pri učenju stranog jezika.

Rezultati koji se odnose na strah od negativne evaluacije poklapaju se s očekivanjima, kao i s nalazima novije studije (Tzoannopoulou, 2016), koji pokazuju da su studenti $\mathrm{s}$ višim stupnjem anksioznosti također skloni većem strahu od negativne evaluacije. Učenje stranog jezika u učionicama često zahtijeva eksplicitnu demonstraciju onoga što je naučeno, stvarajući neugodan kontekst u kojem će se vrednovati studentske sposobnosti. S obzirom na to važno je da se povratne informacije uvijek odnose na konkretno ponašanje, a slijede konstruktivne prijedloge kako se njihova jezična izvedba može poboljšati, umjesto da „pridaje” povratnu informaciju studentskoj osobnosti.

Rezultati ove studije slični su rezultatima dobivenim u prijašnjim istraživanjima (Cheng, Horwitz, i Schallert, 1999; Saito i Samimy, 1996; Sellers, 2000). U svim prethodnim istraživanjima zaključeno je da viši stupanj anksioznosti može štetno utjecati na ukupan uspjeh studenata u učenju stranog jezika, kao i na specifične jezične veštine. Otkrivanjem uzroka anksioznosti pri učenju stranog jezika u smislu osobina i općeg straha od negativne evaluacije mogle bi se ukloniti prepreke s kojima se studenti suočavaju dok javno istupaju na stranom jeziku. Budući da se ova studija nije bavila stupnjem poznavanja stranog jezika, to bi trebalo uključiti u buduće studije $s$ istim ili sličnim istraživačkim pitanjima kako bi se testiralo, na primjer, ovisi li veza između osobnosti i uspješnosti u savladavanju jezika o stupnju anksioznosti pri učenju stranog jezika.

Osim toga, tvrdi se da Skala anksioznosti pri učenju stranog jezika mjeri anksioznost koja je ponajprije vezana uz kontekst govora, budući da se većina stavki iz te skale odnosi na anksioznost pri govoru (Aida, 1994). Neke stavke iz upitnika pokazuju da postoji potreba za ispitivanjem kako lingvističkih, tako i sociolingvističkih čimbenika u vezi s govorenjem stranog jezika. Anksioznost pri verbalnoj komunikaciji na stranom jezikom ponajprije se odražava u naporima učenika da budu što precizniji. Štoviše, anksioznost pri verbalnoj komunikaciji na stranom jeziku može biti posljedica općeg straha od negativne evaluacije, kao i straha od negativne evaluacije od vršnjaka i nastavnika. Stoga sociolingvistički čimbenik anksioznosti u razrednoj situaciji može dovesti do smanjenja napora studenta i slabog učinka u razredu. S obzirom na to da anksioznost pri učenju stranog jezika potječe iz negativne evaluacije, ulogu nastavnika u razredu treba dopuniti time da primijeni strategije koje potiču spremnost na komunikaciju sa studentima i spriječi pojave koje mogu dovesti do smanjenja njihova samopoštovanja (McIntyre, 1999). 
Naš strah od toga da ćemo biti loše ocijenjeni od drugih dio je brojnih društvenopsiholoških fenomena, uključujući prosocijalno ponašanje, prilagođavanje, samopokazivanje, društvenu anksioznost, pripisivanje zasluga samom sebi, promjenu stavova, samohendikepiranje, usuglašavanje i društveno olakšanje (Schlenker, 1980). Osobe s velikim strahom od negativne evaluacije nastoje izbjeći prilike u kojima do toga može doći, pa su stoga otvorenije prema situacijskim čimbenicima koji su u tome relevantni od osoba koje manje strahuju od tuđih ocjena.

Najzad, treba naglasiti da je najveći postotak varijance u varijabli koji je služio kao kriterij u regresivnim modelima objašnjen kontrolnim varijablama, ukazujući na to da veoma važan čimbenik u nastanku anksioznosti pri učenju stranog jezika predstavlja to kako studenti ocjenjuju vlastite sposobnosti za izražavanje na stranom jeziku. To također znači da u budućim istraživanjima te varijable treba kontrolirati, da bi rezultati bili pouzdaniji. Zato je važno razgovarati sa studentima o njihovim očekivanjima iz nastave i vlastitoj izvedbi. Pretpostavljamo da nastavnici često nisu svjesni činjenice da njihov dojam o nečijem znanju nije u skladu s mišljenjem koje student ima za sebe. Ako se o tome otvoreno raspravlja unutar grupe, strah od učenika mogao bi se potencijalno smanjiti. U skladu s tim prijedlogom također je odsustvo značajnog prediktivnog doprinosa za varijablu koja se odnosi na dužinu trajanja učenja engleskog jezika, što može biti tumačeno u svjetlu preostalih rezultata. Iako se čini intuitivnim da će duže učenje jezika pridonositi većoj sigurnosti u znanje i redukciji jezične anksioznosti, čini se da nad ovim „objektivnim“ pokazateljem prevladavaju subjektivni doživljaj kompetentnosti i određene dispozicijske karakteristike. Uzorak istraživanja treba proširiti i uključiti druge profile studenata, kao i dodatna mjerila za anksioznost kao osobinu i stanje anksioznosti.

Iako je ovo prva studija, prema našem znanju, koja istodobno pokriva čitav raspon dimenzija ličnosti iz modela velikih pet, sveukupne razine anksioznosti učenja stranih jezika, njezinih potkomponenata i straha od negativne evaluacije, važno je istaknuti njezina ograničenja. Potrebno je ponoviti rezultate s pomoću većeg uzorka drugih studenata, osim onih s Fakulteta tehničkih znanosti, kako bi se povećala njihova generalibilnost. Osim toga, rezultati završnog ispita trebaju se koristiti kao objektivna mjera učenja jezika. Važno je procijeniti kako anksioznost stranog jezika može utjecati na ukupnu uspješnost studenata i što se može učiniti kako bi se njezini štetni učinci na ocjene studenata mogli smanjiti.

\section{Zaključak}

Rezultati ovog istraživanja u skladu su s istraživanjima koja ukazuju na vezu između osobina i jezične anksioznosti (Dewaele, 2002; Dewaele, 2013; Goh, Dillon, i Goh, 2016). Osim toga, ispitana je uloga osobnosti kao prediktora anksioznosti koja je ispitana i u studiji Er i sur. (2016). Rezultati pokazuju da studenti s niskim stupnjem Emocionalne stabilnosti obično imaju predispoziciju za negativnije emocionalne reakcije, budući da interpersonalnu komunikaciju doživljavaju na neugodniji 
način. Stoga učenici s niskim stupnjem Emocionalne stabilnosti pokazuju sklonost zabrinutosti u pogledu svog uspjeha, očekujući negativan ishod. Koncentrirani su na moguće pogreške u svojoj prezentaciji znanja jezika, pa zbog toga generiraju stanje anksioznosti u situacijama kada trebaju pokazati da su ovladali znanjem i fluentnošću u stranom jeziku. Značajan nalaz predstavlja to da visok stupanj emocionalne stabilnosti nagoviješta manju anksioznost pri učenju stranog jezika, što se može objasniti smirenošću i sabranošću emocionalno stabilnih osoba, što ih čini manje podložnima stresu kada moraju komunicirati na stranom jeziku.

Ovo istraživanje provedeno je da bi se ispitala veza između pet velikih čimbenika i jezične anksioznosti, budući da su takve studije ograničene i rijetke, premda je za osobine kao što su savjesnost utvrđeno da predstavljaju pouzdane prediktore akademskog uspjeha, da su u pozitivnoj korelaciji s potiskivanjem anksioznosti putem usmjeravanja na zadatak i da smanjuju razinu stresa kod studenata u obrazovnom kontekstu (Deary i sur., 1996; Poropat, 2009). Rezultati ove studije u skladu su s prethodno dobivenim rezultatima i važni su budući da se radi o prvom istraživanju provedenom na sveučilišnoj razini kako u Srbiji, tako i u istočnoj Europi.

Osim toga, u ovoj studiji ispituje se veza između anksioznosti i straha od negativne evaluacije, čemu u srpskom i istočnoeuropskom sveučilišnom kontekstu do sada nije posvećivana pažnja. Dobiveni rezultati ukazuju na negativan odnos između anksioznosti pri učenju stranog jezika i straha od negativne evaluacije, neovisno o pet osobina ličnosti. Te nalaze potvrđuju i rezultati prijašnjih studija (Aida, 1994; Cheng, Horwitz, i Schallert, 1999; Sellers, 2000; Tzoannopoulou, 2016).

Pedagoške implikacije ovog istraživanja odnose se na potrebu uvođenja nastavnih pristupa koji uvažavaju određene dimenzije osobnosti kako bi umanjili razinu napetosti $\mathrm{u}$ razrednom odjelu s obzirom na to da jezična anksioznost ima izrazito negativan utjecaj na učenje stranog jezika kod nekih studenata. Na satima stranog jezika potrebno je uvesti i stimulirati atmosferu opuštenog dijaloga uz međusobno uvažavanje, a kod studenata izgraditi svijest o empatiji i toleranciji. Nastavnici trebaju pomoći studentima da nadiđu nerealna očekivanja o učenju jezika tako što studente trebaju podsjetiti na to da uspješno učenje podrazumijeva i činjenje pogrešaka i da one nisu pokazatelj neuspjeha. Učenike treba poticati na dijalog i aktivno sudjelovanje u nastavi tako što im nastavnik treba pružiti osjećaj sigurnosti. Nastavni materijal treba biti na odgovarajućoj jezičnoj razini da bi stimulirao studente da aktivno sudjeluju u nastavnom procesu, a pri tome ih treba poticati na to da prepoznaju i umanje jezičnu anksioznost u okviru individualnih razlika. Studenti mogu pronaći kreativne načine rješavanja svojih problema tako što će podijeliti osjećaj anksioznosti i nelagodnosti sa svojim vršnjacima.

Iz dobivenih rezultata proistječe nekoliko pravaca za daljnja istraživanja. Buduća istraživanja koja bi bila usmjerena na vezu između anksioznosti pri učenju jezika i strategija učenja, spola i osobnosti mogla bi dodatno provjeriti dobivene rezultate. Osim toga, daljnje empirijske studije i drugačiji instrumenti pridonijeli bi razjašnjenju načina na koji studenti uče. 